\title{
Socially Conscious Ventures and Experiential Learning: Perceptions of Student Engagement
}

\author{
William Vasbinder, William Koehler
}

School of Management, Bay State College, United States

Copyright $(2015$ Horizon Research Publishing All rights reserved.

\begin{abstract}
This qualitative study explored stakeholder perceptions of the outcomes of semester-long experiential learning projects in five selected business courses at a small, private college. Students worked with the owners of socially conscious startup firms to develop and present strategic marketing and business plans. The work draws upon interviews with the business owners and faculty, as well as firsthand observations, to assist in identifying factors that promote or hinder student engagement in experiential learning initiatives.
\end{abstract}

Keywords Socially Conscious Ventures, Experiential Learning, Marketing and Managerial Strategies

\section{Introduction}

This research examines stakeholder perceptions of student engagement in cooperative learning projects with local small businesses. In this study, students participated in semester-long experiential assignments, working with local entrepreneurs to create marketing and managerial strategies designed to improve the businesses under study. The firms in question were identified by the researchers as "socially conscious ventures", profit-oriented businesses that incorporate strong social and/or environmental concerns into their businesses. These experiential projects required students to collect both primary and secondary data: to meet with the principals, key employees, customers, and competitors of the firms in question, to make firsthand observations of the firms' operations, and to conduct secondary research on the firm, The researchers' principal working hypothesis is that the explicit social missions of the firms utilized for these pedagogical projects would engender greater interest and engagement among the students involved. This research draws upon extensive semi-structured interviews with the faculty members and entrepreneurs involved in the project in order to ascertain perceived level of student engagement.

In designing this program and research project, we drew upon the seminal work of Kolb [1], employing the concepts of concrete experience, reflective observation, abstract conceptualization, and active experimentation. Experiential learning, a pedagogical paradigm dating from John Dewey's Experience and Education [2], has become an essential component of many business curricula, one intended to advance both student learning outcomes and professional readiness (e.g., McCarthy \& McCarthy [3]; Devasagayam, Johns-Masten, \& McCollum [4]; Ord [5]; Borredon, Deffayet, Baker, \& Kolb [6]). Such experiential learning, as outlined by McCarthy and McCarthy, involves hands-on, practically focused learning experiences and project-oriented pedagogical techniques [3]. Employers in particular welcome such approaches, privileging pragmatically focused educational methods over traditional classroom-only ones [7]. Service learning, a community-focused strand within experiential learning, has recently gained traction-largely in response to the growing number of corporate ethics scandals - as educators and administrators seek to imbue students with broader societal values and a strong moral compass. Some research suggests, however, that both students and employers view these "pure" service-learning experiences as less useful than private-sector experiential learning activities and that such philanthropic endeavors can result in lowered community involvement and empathy among participants [8-10]. To address pervasive ethical concerns while maintaining a focus on professionally useful experience, the authors worked with a set of five "socially conscious ventures", i.e., for-profit small businesses that prioritize economic sustainability, but nevertheless maintain an explicit and meaningful commitment to the social and/or environmental components of the "triple-bottom line."1

\section{Background}

\section{Experiential Learning}

The literature on experiential learning is of course rather

1 The term "triple-bottom line" refers to a business model in which organizations measure and report performance in terms of not only financial, but also social and environmental factors. See, for example, Alhaddi [11]. 
vast, but nevertheless reflects a rather positive consensus on the value obtained from such pedagogical approaches, particularly in business fields. Researchers have identified the positive impacts experienced by businesses that participate in such projects [12], the benefits for student motivation through the inclusion of experiential projects [13], and even increases in students' perceptions of self-efficacy [14]. Moreover, participation in experiential learning projects has been found to enhance students' later career success, especially when carried out in a small business or entrepreneurial context [15].

\section{Service Learning}

An important trend in higher education over the past twenty years is service learning, a type of experiential learning focused on community service as a learning opportunity. The increasing number of recent corporate ethical scandals, including those at Parmalat, HealthSouth, MCI/WorldCom, Tyco, Lehman Brothers, and, of course, Enron, have fuelled the introduction of such programs in business schools nationwide. Campus Compact, the leading North American postsecondary organization devoted to the promotion of service learning, defines it as a pedagogical approach in which "academic instruction and community service are combined with reflection and critical thinking" [16, p. 131]. In service-learning projects, students, under faculty guidance, design and carry out community-based service projects and reflect upon them in light of their experiences and business education [17]. The purported benefits of such educational approaches are numerous and include greater ethical awareness on the part of students and faculty, stronger college-community relations, and hands-on experience for students, as in traditional experiential learning [18].

A growing number of researchers, however, have identified drawbacks inherent in service-learning approaches [19], citing not only faculty and student resistance to such projects, but also reluctance on the part of community organizations to take part in these projects. Additional concerns arise when the faculty member appears to have a vested interest in promoting a particular community partner for service learning, bringing issues of conflict of interest and student coercion [8, 20]. Additionally, many students question the value of such projects for business education, insofar as the types of challenges, work, and organizational emphases found in typical service-learning endeavors often differ markedly from those in the corporate world for which business students are ostensibly preparing [21-22]. The research consensus is that students place the highest value on project-based learning that most closely resembles the private-sector placements the students expect to assume upon graduation [14].

\section{Socially Conscious Ventures}

After management emerged as an academic discipline in the early twentieth century, 2 its focus remained almost exclusively on the for-profit enterprise, and on profit itself. In the last two decades, though, significant scholarship concerning management of not-for-profit entities, corporate social responsibility, and sustainability has appeared and gained broader acceptance. Only very recently, however, have researchers begun to develop a more nuanced understanding of the range of business models falling on the wide spectrum between for- and not-for-profit entities. Whether labeled as socially conscious firms [24] socially responsible corporations [25], B corporations [26], or for-benefit enterprises [27], such organizations share a dual commitment both to financial and to social/environmental sustainability [28-30]. The term "Gray-Sector Organizations", or GSOs, has been coined to describe businesses that combine social, environmental, and economic sustainability in their design and mission [31]. Firms in these categories have been rather neglected as topics for research, even though this emphasis on corporate ethics, social responsibility, and mission appears to reflect a broad-based societal movement toward renewed scrutiny of corporate behavior [14, 32]. Previously, philanthropic endeavors, ranging from charitable contributions to firm-sponsored volunteering, were considered sufficient actions for corporations to demonstrate their commitment to corporate citizenship and to benefit from positive public relations surrounding such activities [33]. The recent success of brands that emphasize a mission-centered approach to social responsibility, ranging from Whole Foods to Seventh Generation, from Tom's Shoes to Tesla Motors, from Ben \& Jerry's to Patagonia, testifies to growing support for firms that take their social and environmental responsibilities very seriously, as employers and product/service providers. For the purposes of this research, we utilize the term "socially conscious ventures" to describe GSO, for-profit businesses for which social responsibility inheres in the firm's mission and DNA, rather than those firms that merely engage in philanthropic activities. Such "embedded" corporate social responsibility, or CSR “involves an organization's core competencies and integrates CSR within a firm's strategy, routines, and operations, and therefore affects all employees" [34, p. 314].

Moreover, a great deal of sociological and consumer research holds that the Millennial generation (also known as Gen Y or the Echo Boomers, the eighty-four-million strong cohort born between about 1983 and 2000) places a particular emphasis on evaluating the firms with which its members do business on a triple-bottom-line basis [35]. Since all but one of the forty-seven students involved in the study were members of this generation, this study seeks in part to evaluate whether the value placed on broader societal

2 The general consensus among business historians is that Frederick W. Taylor's The Principles of Scientific Management, published in 1911 [23] marks the beginning of the discipline of business, as separate from economics, though of course the field continues to draw upon and overlap with economics, as well as other social-science disciplines. 
impacts of businesses extends to experiential learning endeavors as well.

\section{Socially Conscious Experiential Learning}

As noted earlier, demographic, cultural, and societal changes have contributed to increased awareness of, and grass-roots pressure for, corporate transparency and social responsibility. Although social movements such as Occupy Wall Street may represent the most extreme examples, the past decade has seen a dramatic rise in broad expectations for CSR and environmental engagement [36]. At the same time, business education has, rightly, come under fire for its failure to provide sufficient grounding in practical ethics to undergraduate students. This study thus seeks to address both the strong proclivity of the current generation of undergraduate students to demand greater CSR from the business world and the need in business education for more comprehensive inculcation of ethical foundations and behaviors [26].

\section{Research Methodology}

\section{Introduction}

This qualitative study seeks to explore stakeholder perceptions of the outcomes of pedagogical revisions in five selected business courses. The revisions were implemented with the intent of providing the benefits of experiential learning, while emphasizing moral and ethical development without incurring the decrease in community involvement recently attributed to service learning, as noted by various researchers [8-10].

The performance of the students in five courses was assessed in terms of the perceptions of the faculty members that taught the courses and the principals of the socially responsible businesses that were served. These ten sets of interview questions comprised the data for this study. Both the firm principals and the School of Management faculty were asked a series of seven semi-structured interview questions,

\section{Research Questions}

The following research questions guide this study.

Research Question 1. What was the nature of the interaction between the students and entrepreneurs?

Research Question 2. What level of motivation did the students demonstrate throughout the project?

Research Question 3. To what extent did the students seem to identify with the firm's social mission?

Research question 4. How well were the students able to integrate business concepts into the projects they completed with the firm?

Research Question 5. How useful were the strategic insights and recommendations developed by the students?

\section{Design of the Study}

This qualitative study employed a grounded theory design.
The purpose was to assess pedagogical revisions that were intended to provide the benefits of experiential learning while incorporating social responsibility without the long-term aversion to community involvement sometimes attributed to service learning. The performance of students in relation to these revisions was assessed through interviews with the faculty of the following courses: Principles of Marketing, two sections of Marketing Research, Introduction to Entrepreneurship, and Strategic Management. The principals of the businesses served by the students were then interviewed utilizing semi-structured interview questions that aligned with those asked of the faculty.

\section{Construct Validity}

The recorded interviews were transcribed and returned to the interviewees for member checking. Both the content and the intent of the responses were confirmed, thus establishing a chain of evidence, ensuring no evidence was "lost through carelessness or bias" [37, p. 123]. The study's construct validity was reinforced further buy using multiple sources of evidence. In this study both faculty and principals provided sources of evidence.

\section{Internal and External Validity}

Since the researchers in this study are not attempting to establish causality or generalize to a larger population, internal and external validity will not be discussed here. The purpose, as stated earlier, is to establish a grounded theory which would be subject to additional study.

\section{Reliability of the Design}

Reliability implies that later researchers should be able to replicate the study, its findings, and its conclusions. The interview protocols have been included in the appendices for this purpose.

\section{Population and Sample}

Within this college, the four-year programs in the School of Management include programs leading to Bachelor's degrees in Management with concentrations in Management, Marketing, Hospitality Management, Finance, Healthcare Management, and Management Information Systems, as well as separate Bachelor's degrees in Information Technology, Entertainment Management, and Fashion Merchandising. The purposeful sample of principals and faculty was comprised of those individuals directly involved in the pedagogical revision and subsequent implementation, as well as of principals in the firms in question. According to Creswell's authoritative book Research Design [38], "a purposeful sample in qualitative research is desirable and occurs when investigators select individuals and sites that are likely to help them to understand the characteristics of the phenomenon they are studying".

\section{Data Collection Instruments}

Faculty members from the School of Management at the College, along with the principals of the socially responsible 
businesses, were interviewed about the performance of students as defined by the research questions.

\section{Protection of Human Subjects}

The human subjects review process was completed as required by the Human Subjects Committee of the college in this study (Appendix I). Interviewees (both principals and faculty) were presented with the informed consent form prior to the administration of the interview.

According to Creswell [38] it is important to protect the identity of the informants when gathering, analyzing, and reporting data. The confidentiality of participants was maintained throughout this study. Materials (interview responses) were not coded in any identifiable way. All data were reported either in aggregate, or using pseudonyms.

The data collected from this investigation will be kept for a period of five years, to allow for data verification and confirmation of results and analysis. After five years, all data and analysis (digital and paper) will be destroyed.

\section{Data Analysis}

The qualitative data generated by both the principal and faculty interviews were extracted from the transcriptions of the interviews and the subsequent open-coding. According to Creswell [38, p. 186], coding involves "taking text data or pictures gathered during data collection, segmenting sentences (or paragraphs) or images into categories, and labeling those categories with a term". This process was used in the analysis of the interview transcriptions.

\section{Presentation of the Findings}

Introduction
The qualitative instruments used in this study consisted of two sets of semi-structured interview questions. The faculty completed a seven-question interview with questions pertaining to the students' "buy in" with regard to the missions of the firms, their commitment and engagement with the projects, the quality of their suggestions, the students' overall business knowledge, and the likelihood of the principals implementing the recommendations created by the students. The principals of the socially responsible firms completed a seven-question open-ended interview with questions that were closely aligned with those answered by the participating faculty members.

The qualitative data generated by both the faculty and principals' interviews were extracted from the transcriptions of the interviews and the subsequent open coding. The codes were entered into a matrix to facilitate the generation of frequencies.

\section{Research Site and Participant Characteristics}

The faculty members in the study were professors in the School of Management who had recently taught courses that included an experiential project, working with for-profit businesses that prioritize economic sustainability but nevertheless maintain an explicit and meaningful commitment to the social and/or environmental components of the "triple-bottom line," as outlined above.

The principals of these socially conscious firms comprised the second group of participants. These entrepreneurs all maintained that social responsibility was both an inseparable aspect of the mission of their business and a necessary element in their quest for long-term viability and sense of purpose for their firms.

Table 1. Data Source and Analysis Chart

\begin{tabular}{|l|c|c|}
\hline $\begin{array}{l}\text { Interview question 1. Tell us about your experiences } \\
\text { working with students on this project. }\end{array}$ & Interviews with faculty and principals & Open coding \\
\hline $\begin{array}{l}\text { Interview question 2. What was your impression of the } \\
\text { level of commitment/engagement of the students? }\end{array}$ & Interviews with faculty and principals & Open coding \\
\hline $\begin{array}{l}\text { Interview question 3. To what extent did the students } \\
\text { seem to "buy into" the mission of the firm? }\end{array}$ & Interviews with faculty and principals & Open coding \\
\hline $\begin{array}{l}\text { Interview question 4. How well were the students able } \\
\text { to integrate business concepts into the projects they } \\
\text { completed with the firm? }\end{array}$ & Interviews with faculty and principals & Open coding \\
\hline $\begin{array}{l}\text { Interview question 5. How well did the strategic } \\
\text { insights and recommendations offered by the students } \\
\text { match your own vision for the firm? }\end{array}$ & Interviews with faculty and principals & Open coding \\
\hline $\begin{array}{l}\text { Interview question 6. Were the students able to offer } \\
\text { useful data and suggestions? }\end{array}$ & Interviews with faculty and principals & Open coding \\
\hline $\begin{array}{l}\text { Interview question 7. To what extent do you believe } \\
\text { the principal will incorporate recommendations or } \\
\text { observations from the students into the operations or } \\
\text { strategic planning for the firm? }\end{array}$ & Interviews with faculty and principals & Open coding \\
\hline
\end{tabular}




\section{Findings}

Finding 1. The faculty responses to question 1: Tell us about your experiences working with students on this project, garnered unanimous positive remarks. The responses included "very positive" and "overall positive". Among the verbatim responses were "students continued to work with the principal after the project was over" and "the students like the project and the entrepreneur".

Finding 2. The second question asked of the faculty was: What was your impression of the level of commitment/engagement of the students? All of the participants indicated very high engagement. The professors in 2 of the courses said that engagement was "considerably greater" than that they had seen when teaching the same material via case studies in earlier iterations of the course. Faculty in three of the courses commented that the principals had offered the students forms of extrinsic motivation.

Finding 3. The third question was: to what extent did the students seem to "buy into" the mission of the firm? While all affirmed the "buy in" of students, the comments also indicated that the strength of the "buy-in" was positively correlated to the clarity of the communication of the mission by the principals. One faculty member observed that the "students were most inspired by the entrepreneurs who offered a compelling story" for the socially conscious aspects of the firm's mission.

Finding 4. Faculty question four was: how well were the students able to integrate business concepts into the projects they completed with the firm? All of the faculty members interviewed indicated that the students readily applied business concepts that had been included in the curricula of organizational behavior, various marketing courses, and various management courses. For two of the student groups, professors remarked that they were dissatisfied with students' abilities with financially related tasks, such as financial statement analysis and revenue projections.

Finding 5. Question 5 directed to faculty was: How well did the strategic insights and recommendations offered by the students match your own vision for the firm? The response of all was rated "very well", but all respondents had presented the students with their own vision for the firm during class discussion, and as such students. All commented that although they had led the students initially, the students then went well beyond the prompts offered by the instructors.

Finding 6. The sixth question of the faculty interviews was: Were the students able to offer useful data and suggestions? The response was affirmative for all five of the courses, but with variability regarding how useful. Students from three of the five classes provided more useful suggestions than data. Students from the remaining two classes offered data-based suggestions that were deemed by the principals as very useful. One of these two envisioned a different target market than the principal, so although the suggestions are sound, some were not aligned with the principal's vision.
Finding 7. To what extent do you believe the principal will incorporate recommendations or observations from the students into the operations or strategic planning for the firm? This was the final question posed to faculty. It can be observed at all five of the businesses that many of the suggestions are already in place. Several of the improvements suggested were minor "tweaks" to operations, but many others represented substantial, even transformational, alterations in target market, product mix, and even business model.

The next section presents the findings from the interviews with the principals of the firms. The questions are designed to align with the faculty questions above.

Finding $1 a$. The first question asked of the principals was: Tell us about your experiences working with students on this project. All of the principals indicated that the experience was positive, and remarked that the students exhibited a professional demeanor.

Finding 2a. The second question asked: What was your impression of the level of commitment/engagement of the students? All of the principals interviewed noted high level of engagement, all used terms like eager and committed, one remarked that the students were "all in".

Finding $3 a$. This question asked: To what extent did the students seem to "buy into" the mission of your firm? All of the entrepreneurs said that students bought-in to the mission, two indicated partial buy-in, and two could not be sure if buy in was complete or partial.

Finding $4 a$. The fourth question posed to the principals was: How well were the students able to integrate business concepts into the projects they completed with your firm? Four of the five principals said the integrated concepts very well, 1 indicated partial integration. One of the business owners remarked "they are business students, they get it".

Finding $5 a$. The fifth question for the entrepreneurs was: How well did the strategic insights and recommendations offered by the students match your own vision for the firm? Three of the principals said the match was very good, one said the insights were a partial match. The fifth business owner said the students' vision did not match his.

Finding $6 a$. The sixth question was: Were the students able to offer useful data and suggestions? All of the principals indicated that the suggestions were useful. Two of the interviewees liked all of the suggestions, while the remaining three said that at least some of the students' suggestions had merit.

Finding $7 a$. The seventh and final question asked: To what extent will you incorporate recommendations or observations from the students into your operations or strategic planning? All of the entrepreneurs replied that they are already using one or more of the students' suggestions. These are primarily in operations. It proved difficult to determine what portion of the students' contributions would find its way into the strategic planning of the firms. None of the five would divulge their future strategic plans in any detail. 


\section{Discussion and Limitations}

Evidence from the faculty and principals involved in this study support the authors' two working hypotheses, namely that (1) students would show higher levels of engagement and enthusiasm for experiential learning projects centered on socially conscious firms, and that (2) utilizing such for-profit enterprises would ameliorate the negative student responses to "pure" service-learning endeavors. The business principals and faculty generally reported that the students in these five courses not only displayed high levels of engagement in the projects in question, but also embraced the social missions of the firms. This result moreover appeared to be independent of the types of businesses utilized for the study. Similarly, students seemed to respond well to the for-profit nature of the firms in question and were thus able to apply theoretical understanding derived from their management education to the projects. Although not central to this research, the strong business benefits reported by the entrepreneurs provide another dimension of reciprocal utility and suggest several avenues for future inquiry.

The results therefore suggest that socially conscious ventures may indeed represent a fruitful avenue for pursuing multiple objectives in business pedagogy [31]. The employment of gray-sector organizations as loci for experiential learning approaches appears to hold strong merit in enhancing student engagement and commitment with regard to such projects. Additionally, neither the faculty nor the principals involved reported any of the resistance frequently associated with pure service-learning endeavors, suggesting that again this approach may offer benefits for ethics education in business. The advantages accruing to the firms and entrepreneurs that participated in the five projects moreover implies that such pedagogical approaches may impart significant reciprocal externalities for small business development and community-building as well.

\section{Limitations}

By its very nature, this exploratory, qualitative study is somewhat limited in its broader applicability. The small number of respondents may skew the results considerably, due either to bias or to the particular nature of the firms and individuals in question. As participant-observers, the faculty members in question may similarly have influenced the results of study through their interactions with the students and business principals, perhaps engendering confirmation bias [39]. It is also problematic to extrapolate these results to other educational institutions, academic disciplines, or geographic regions, insofar as the results presented may derive from the peculiar nature of the institution or locality, rather than from the nature of the investigation. Moreover, since this research did not directly evaluate different modes of experiential learning, the lack of a broader comparative framework diminishes the explanatory value of the research. Finally, to the extent that the research focused exclusively on external measures of student engagement, efficacy, and embeddedness, the students' own perceptions of these dimensions were not considered and could vary substantially from those reported by the faculty members and entrepreneurs.

\section{Directions for Future Research}

As noted above, the limitations of this study suggest several clear paths for supplementary inquiry. The authors had already intended to conduct a second phase of research centered on the students who participated in this study. The authors plan to conduct a series of semi-structured interviews with the sixty-eight students involved in these experiential learning projects. Additionally, the authors recognize the need for a stronger comparative dimension in this area and would thus recommend a parallel study that examines both experiential learning without a socially conscious dimension and pure service learning. Such an approach would enable more definitive conclusions regarding the effects of socially conscious ventures on student engagement. Scholarship on similar interventions at different educational institutions and in other geographical areas may likewise offer great heuristic value.

\section{Conclusions}

This qualitative work explores stakeholder assessments of student engagement and efficacy in a series of five experiential learning projects in business classes at a private, four-year college. . The private-sector partners chosen for this exercise were five local businesses with strong elements of social consciousness in their mission and operations. The authors hypothesized that combining two elements that have been found to appeal to students - a profit orientation and a triple-bottom-line strategic approach - would result in high levels of student engagement. The authors also expected that student resistance to these efforts would be less than that reported in many pure service-learning projects. Extensive semi-structured interviews with the entrepreneurs and faculty members suggest that both initial suppositions were correct, as all interviewees reported high levels of perceived student engagement. Interview data similarly imply that the student participants not only embraced the missions of the firms in question, but were also able to apply theoretical lessons from their undergraduate business education to the projects.

\section{Appendix I: Faculty Interview guide}

\author{
Protocol \\ Introduction \\ Consent form \\ Point out phone numbers for Researchers and \\ Institutional Review Board \\ Interview questions \\ Thank participant for contributing to research \\ Ask if participant has questions
}


Remind participant of the level of caution given to protect their anonymity

1. Tell us about your experiences working with students on this project?

2. What was your impression of the level of commitment/engagement of the students?

3. To what extent did the students seem to "buy into" the mission of the firm?

4. How well were the students able to integrate business concepts into the projects they completed with the firm?

5. How well did the strategic insights and recommendations offered by the students match your own vision for the firm?

6. Were the students able to offer useful data and suggestions?

7. To what extent do you believe the principal will incorporate recommendations or observations from the students into the operations or strategic planning for the firm?

\section{Appendix II: Principals Interview guide}

\section{Protocol}

Introduction

Consent form

Point out phone numbers for Researchers and Human

Subjects Committee

Interview questions

Thank participant for contributing to research

Ask if participant has questions

Remind participant of the level of caution given to protect their anonymity

1. Tell us about your experiences working with students on this project?

2. What was your impression of the level of commitment/engagement of the students?

3. To what extent did the students seem to "buy into" the mission of your firm?

4. How well were the students able to integrate business concepts into the projects they completed with your firm?

5. How well did the strategic insights and recommendations offered by the students match your own vision for the firm?

6. Were the students able to offer useful data and suggestions?

7. To what extent will you incorporate recommendations or observations from the students into your operations or strategic planning?

\section{Appendix III: Informed Consent}

\author{
Experiential and Service Learning: Stakeholder \\ Interviews
}

The purpose of study is to assess the effectiveness of socially conscious experiential approaches to student learning and ethical development while also evaluating the value derived by the firms in question.

- You must be 18 years or older to participate in this interview.

- Completing the interview is voluntary and will not affect your grade in any course.

- You may choose not to complete the interview. Simply inform the interviewer that you do not wish to continue.

- You may withdraw at any time.

- You may skip questions.

- Risks of participation in the interview are not greater, considering probability and magnitude, than those ordinarily encountered in daily life.

- It will take you about $\mathbf{3 0}$ minutes to complete the interview.

- By participating in this study, you may add to existing the knowledge base on how undergraduate students develop their leadership abilities.

- Information will be used in presentations and publications.

- Your name will not be associated with your responses.

- The interview will be audio-taped and transcribed.

- All your responses will be grouped with the responses of others.

- The data will not be coded in any identifiable way.

- All data will be reported in aggregate.

- All interview responses will be stored in a locked file cabinet.

- All survey responses will be destroyed upon completion of the study.

- If you have any questions about your rights as a research subject, please contact the Bay State College Institutional Review Board at 617-217-9305. The IRB is a group of people that reviews research studies and protects the rights of people involved in research.

\section{REFERENCES}

[1] Kolb DA. Experiential Learning: Experience as the Source of Learning and Development. Englewood Cliffs, NJ: Prentice-Hall; 1984.

[2] Dewey J. Experience and Education. New York: The Macmillan Company; 1938.

[3] McCarthy PR, McCarthy HM. When case studies are not enough: Integrating experiential learning into business curricula. In Journal of Education for Business. 2005; 81(4): 201-204.

[4] Devasagayam R, Johns-Masten K, McCollum J. Linking information literacy, experiential learning, and student characteristics: Pedagogical possibilities in business education. In Academy of Educational Leadership Journal. 2012; 16(4): $1-18$. 
[5] Ord J. Experiential learning in youth work in the UK: A return to Dewey. In International Journal of Lifelong Education. 2009; 28(4): 493-511.

[6] Borredon L, Deffayet S, Baker AC, Kolb D. Enhancing deep learning: Lessons from the introduction of learning teams in management education in France. In Journal of Management Education. 2011; 35(3): 324.

[7] Gault J, Leach E, Duey M. Effects of business internships on job marketability: The employers' perspective. In Education \& Training. 2010; 52(1): 76-88.

[8] Geldenhuys DJ, Cilliers F. Transforming a small business: a learning intervention. In South African Journal of Industrial Psychology. 2012; 38(2): 1-8.

[9] Higgins D, Aspinall C. Learning to learn: A case for developing small firm owner/managers. In Journal of Small Business and Enterprise Development. 2012; 18(1): 43-57.

[10] Dipadova-Stocks L. Two major concerns about service-learning: What if we don't do it? What if we do? In Academy of Management Learning \& Education. 2005; 4(3): 345-353.

[11] Alhaddi H. The influence of triple bottom line on strategic positioning: An exploratory case study on differentiation through image. In Journal of Management and Strategy. 2014; $5(1): 55$.

[12] DeSimone F, Buzza J. Qualitative pedagogical findings to improve critical thinking skills. In American Journal of Business Education. 2013; 6(6): 631

[13] Baden D, Parkes C. Experiential learning: Inspiring the business leaders of tomorrow. In The Journal of Management Development. 2013; 32(3): 295-308.

[14] Peltier JW, Scovotti C. Enhancing entrepreneurial marketing education: The student perspective. In Journal of Small Business and Enterprise Development. 2012; 17(4): 514-536.

[15] Woodier-Harris N. Evaluating the impact of SPEED on students' career choices: A pilot study. In Education \& Training. 2010; 52(6): 463-476.

[16] Casile M, Hoover KF, O'Neil DA. Both-and, not either-or: Knowledge and service-learning. In Education \& Training. 2011; 53(2): 129-139.

[17] Meringolo DD. The place of the city: Collaborative learning, urban history, and transformations in higher education. In Journal of Urban History. 2014; 40(3): 419.

[18] Flinders BA. Service-learning pedagogy: Benefits of a learning community approach. In Journal of College Teaching \& Learning. 2013; 10(3), 159.

[19] Lester SW, Tomkovick C, Wells T, Flunker L, Kickul J. Does service-learning add value? Examining the perspectives of multiple stakeholders. In Academy of Management Learning \& Education. 2005; 4(3): 278-94.

[20] Kolenko TA, Porter G, Wheatley W, Colby M. A critique of service learning projects in management education: pedagogical foundations, barriers, and guidelines. In Journal of Business Ethics. 1996; 15(1): 133-42.

[21] Vega G. Teaching business ethics through service-learning metaprojects. In Journal of Management Education. 2007; 31(5): 647-666, 668-678.
[22] Seider SC, Gillmor SC, Rabinowicz SA. The impact of community service learning upon the worldviews of business majors versus non-business majors at an American university. In Journal of Business Ethics. 2011; 98(3): 485-503.

[23] Taylor FW. The Principles of Scientific Management. New York; 1911.

[24] Chase DG, Burns DJ, Claypool GA. A suggested ethical framework for evaluating corporate mergers and acquisitions. In Journal of Business Ethics. 1997; 16(16): 1753-1763.

[25] Sethi SP. Globalization and the good corporation: A need for proactive co-existence. In Journal of Business Ethics. 2003; 43(1): 21-31.

[26] André R. Assessing the accountability of the benefit corporation: Will this new gray sector organization enhance corporate social responsibility? In Journal of Business Ethics. 2012; 110(1): 133-150

[27] Sabeti H. The for-benefit enterprise. In Harvard Business Review. 2011; 89: 98-104.

[28] Dorado S. Social entrepreneurial ventures: Different values, so different process of creation, no? In Journal of Developmental Entrepreneurship. 2006; 11(4), 319-343.

[29] Fadahunsi A. The growth of small businesses: Towards a research agenda. In American Journal of Economics and Business Administration. 2012; 4(1): 105-115.

[30] Gawell M. Social entrepreneurship: Action grounded in needs, opportunities and/or perceived necessities? In Voluntas. 2013; 24(4): 1071-1090.

[31] Hiller JS. The benefit corporation and corporate social responsibility. In Journal of Business Ethics. 2013; 118(2): 287-301

[32] Clark C, Brennan L. Entrepreneurship with social value: A conceptual model for performance measurement. In Academy of Entrepreneurship Journal. 2012; 18(2), 17-39.

[33] Marquis C, Lee M. Who is governing whom? Executives, governance, and the structure of generosity in large U.S. firms. In Strategic Management Journal. 2013; 34(4), 483.

[34] Aguinis H, Glavas A. Embedded versus peripheral corporate social responsibility: Psychological foundations. In Industrial and Organizational Psychology. 2013; 6(4): 314-332.

[35] Hyllegard K, Ogle J, Yan R. The impact of advertising message strategy - fair labour v. sexual appeal - upon gen Y consumers' intent to patronize an apparel retailer. In Journal of Fashion Marketing and Management. 2009; 13(1): 109-127.

[36] Glunk U, Smits M. Awakening world-changing leadership through management education. In The Journal of Corporate Citizenship. 2010; (39), 87-91.

[37] Yin R. Case Study Research Design and Methods. Thousand Oaks, CA: Sage, Inc; 2009.

[38] Cresswell J. Research Design: Qualitative, Quantitative, and Mixed Methods Approaches. Thousand Oaks, CA: Sage, Inc; 2008.

[39] Lam C. (2007). Is Popper's falsificationist heuristic a helpful resource for developing critical thinking? In Educational Philosophy and Theory. 2007; 39(4): 432-448. 